\title{
Clonal variation in above- and below-ground growth responses of Populus tremuloides Michaux: Influence of soil warming and nutrient availability
}

\author{
John S. King ${ }^{1, *}$, Kurt S. Pregitzer ${ }^{1}$ and Donald R. Zak ${ }^{2}$ \\ ${ }^{1}$ School of Forestry and Wood Products, Michigan Technological University, Houghton, MI 49931, USA and \\ ${ }^{2}$ School of Natural Resources and Environment, University of Michigan, Ann Arbor, MI 48109, USA
}

Received 12 October 1998. Accepted in revised form 5 March 1999

Key words: biomass partitioning, clonal variation, $\mathrm{N}$-availability, Populus tremuloides, root longevity, soil warming

\begin{abstract}
Trembling aspen (Populus tremuloides Michx.) is the most widely distributed tree species in North America making it important to terrestrial carbon and nutrient cycles. Due to anthropogenic climate change high latitude temperatures are expected to increase, making it necessary to assess the feedback between above- and below-ground carbon pools to increased temperature at sites of both high and low $\mathrm{N}$-availability. We grew four clones of aspen at two levels of soil temperature and two levels of soil $\mathrm{N}$-availability for 98 days and quantified photosynthesis, growth, biomass allocation, and root length production and mortality. High soil temperature increased rates of photosynthesis (65\%), resulting in greater whole-plant growth $(37 \%)$ through increases in roots, stems, and foliage; however these increases generally occurred only in soil of high $\mathrm{N}$-availability. Root:shoot biomass allocation varied between clones but was unaffected by the soil temperature or $\mathrm{N}$-availability treatments. Root length production and mortality increased at elevated soil temperature, but this response was modified by soil $\mathrm{N}$-availability. At high soil temperature, soil $\mathrm{N}$-availability had little effect on root dynamics, while at low soil temperature, high soil $\mathrm{N}$ availability increased both the production and mortality (turnover) of roots. We conclude that trembling aspen has the potential for substantially greater growth and root turnover under conditions of warmer soil at sites of both high and low $\mathrm{N}$-availability, but that allometric patterns of growth are under strong genetic, rather than environmental control.
\end{abstract}

\section{Introduction}

The expected increase in average global temperature of 1 to $3.5^{\circ} \mathrm{C}$ within the next 100 years will likely be more pronounced at high northern latitudes in autumn and winter (Houghton et al., 1996). High latitudes are thought to be especially vulnerable to global climate change because of the complex feedbacks between climate, thermohaline circulation of the oceans, the influence of ice and snow cover on surface albedo, and responses of terrestrial plant communities (Houghton et al., 1996; Ganopolski et al., 1998). Shifts in net primary production, biomass partitioning, and carbon cycling in forest ecosystems will play a major role in the biosphere's response to the rising levels of at-

\footnotetext{
* E-mail: jsking@mtu.edu
}

mospheric $\mathrm{CO}_{2}$ (Amthor, 1995; Melillo et al., 1996; Norby et al., 1996) and increasing nitrogen deposition (Galloway et al., 1995; Vitousek et al., 1997). Of particular concern is whether warming of soils at high latitudes will result in these areas becoming net sources, rather than sinks, for atmospheric carbon in the future (Billings et al., 1982; Hobbie, 1996; Oechel and Vourlitis, 1996).

A major process delivering carbon $(\mathrm{C})$ to northern forest soils is the production and turnover of fine roots (Fogel, 1983; Hendrick and Pregitzer, 1993). Whole-plant growth, photosynthesis, and fine root production and turnover have all been shown to be positively correlated to increases in air temperature, nutrient availability, and atmospheric $\mathrm{CO}_{2}$ (Pregitzer et al., 1995; Berntson and Bazzaz, 1996; Tissue et al., 1996). Increased soil temperatures will occur during 
any general warming of the planet (Peterjohn et al., 1994), yet the effects of warmer soils on the dynamics of $\mathrm{C}$ cycling in northern forests has received relatively little attention. Hendrick and Pregitzer (1993) attributed greater rates of fine root mortality in a 'southern' sugar maple forest to higher soil temperature, and Lawrence and Oechel (1983) and Marshall and Waring (1985) have presented evidence that root respiration and turnover increase with soil temperature. Using minirhizotrons, Forbes et al. (1997) have provided some of the first evidence that elevated soil temperature directly decreases root longevity in Lolium perenne $\mathrm{L}$. As both temperature and the availability of certain nutrients are increasing concurrently with atmospheric $\mathrm{CO}_{2}$, it is important to observe the interaction of these other factors on relationships governing carbon storage in northern forest ecosystems.

Trembling aspen (Populus tremuloides Michaux) is the most widely distributed tree species in North America, occurring over a range that spans $111^{\circ}$ of longitude and $48^{\circ}$ of latitude (Perala, 1990). It is a major commercial species, providing fiber for pulp and flakeboard production. Ecologically, it is an earlysuccessional species, occurring on soils of a wide range of $\mathrm{pH}$ and $\mathrm{N}$-availability (Barnes and Wagner, 1981; Perala, 1990). It is very shade intolerant and is characterized by high photosynthetic rates and rapid growth. Regeneration is primarily by vegetative propagation, especially after disturbance, and clonal variation in physiology and phenology may confer an adaptive advantage to some genetic lines in response to changing environmental conditions (Kubiske et al., 1998). Finally, aspen productivity in the Great Lakes region of the midwestern United States has been estimated at $2.9 \mathrm{mg} \mathrm{C} \mathrm{ha}^{-1}$ year ${ }^{-1}$ (live biomass) on good sites managed with a 40-year rotation (Alban and Perala, 1992), illustrating the potential $C$ sink strength of aspen ecosystems across its range.

In order to investigate the effects of increased soil temperature and nutrient availability on carbon gain and loss of an important north-temperate forest species, we grew four clones of aspen for 98 days at two levels of soil temperature and two levels of nutrient availability at the University of Michigan Biological Station, Pellston, Michigan. We hypothesized that: (1) increased levels of soil temperature and $\mathrm{N}$-availability would result in higher photosynthetic rates and greater whole plant growth; (2) growth at elevated soil temperature would be accompanied by increased rates of root production and turnover; and (3) increased nutri- ent availability would decrease biomass allocation to roots regardless of soil temperature.

\section{Methods}

The study site was located at the University of Michigan Biological Station near Pellston, Michigan $\left(45^{\circ} 34^{\prime} \mathrm{N}, 84^{\circ} 40^{\prime} \mathrm{W}\right)$. The experimental plant material consisted of four previously described clones of Populus tremuloides which differ in leaf phenology and physiological characteristics (Barnes, 1959). Two of the clones (42 and 51) are characterized by early-senescing foliage (mid-October) and high photosynthetic rates and two (1 and 8) by late-senescing foliage (mid-November) and relatively lower photosynthetic rates (Kubiske et al., 1998). Roots of each clone were collected at the Biological Station in October 1993, and freshly propagated for this study at the University of Michigan.

On June 17, 1997, cuttings of the clonal material were planted in $3 \mathrm{~L}$ pots, each ramet being randomly assigned to high or low soil $\mathrm{N}$-availability, and high or low soil temperature. The soil media has been described previously (Pregitzer et al., 1995; Randlett et al., 1996) and resulted in levels of $\mathrm{N}$-availability characteristic of the range found across the northern Great Lakes region (Zak and Pregitzer, 1990). Briefly, high $\mathrm{N}$-availability soil consisted of a homogenized Ahorizon of a Kalkaska series soil (sandy, mixed, frigid, Entic Haplorthod) with a net $\mathrm{N}$-mineralization rate of $348 \mu \mathrm{g} \mathrm{N} \mathrm{g}^{-1} \mathrm{~d}^{-1}$. The low $\mathrm{N}$-availability soil was a 4:1 mix of Rubicon series C-horizon soil (sandy, mixed, frigid, Entic Haplorthod) with A-horizon of the Kalkaska series soil; it had a net $\mathrm{N}$-mineralization rate of $45 \mu \mathrm{g} \mathrm{N} \mathrm{g}^{-1} \mathrm{~d}^{-1}$.

Soil temperature was controlled by exposing pots to ambient air temperature (high temperature treatment) or by cooling them with a constant-flow water bath. The water bath consisted of a groundwater supply pumped into sealed wooden boxes, each with an inlet and outlet. Pots were sealed in the boxes with silicone sealant and a drain hole installed beneath each. As the experimental treatments were replicated three times, three cooling boxes were constructed containing 24 pots each. The cooling boxes were randomly interspersed with three boxes of 24 pots built with the same dimensions using $2.54 \mathrm{~cm}$ thick foam insulation. Foam insulation was used to buffer rapid temperature changes over the course of the day. Tenminute soil temperature averages were measured in 
a pot located at the center and edge of two of the high temperature and low temperature groups of pots with chromel-constantan theromcouples connected to a Li-Cor 1000 datalogger. Thermocouples were buried at mid-pot depth and moved to different pots in the same relative locations after each harvest. Plants were exposed to natural light, air temperature and precipitation throughout the course of the study. Volumetric soil moisture in the pots was monitored using a Trane TDR (time domain reflectometry) system and water added during extended dry periods.

Three destructive harvests were conducted at approximately one-month intervals. On the day preceding each harvest, photosynthesis was measured on the plants to be harvested using a LICOR 6400 portable photosynthesis system in open mode equipped with a chamber with internal light source $(670 \mathrm{~nm}$ red LED). Photosynthetic photon flux density (PPFD) was maintained at $1800 \mu \mathrm{mol} \mathrm{m}{ }^{-2} \mathrm{~s}^{-1}$ and the system was calibrated for zero and span at each sample date using a gas standard of known $\mathrm{CO}_{2}$ concentration. Measurements were taken on the most recent fully expanded leaf between 10:00 AM and 14:00 PM Eastern Standard Time. During the harvests, plants were separated into roots (live plus dead), stems and leaves. Roots were extracted from soil by removing pots and spraying low-pressure water through the rootsoil mass suspended over a 2-mm mesh screen. Root systems were carefully inspected for any adhering soil, which was removed by hand. Plant leaf area was measured with a Licor LI-3000 leaf area meter (Licor, Inc., Lincoln, Nebraska). Stem height was recorded and all biomass components were dried to constant weight in a forced air oven at $65^{\circ} \mathrm{C}$.

To monitor root length production and mortality, six glass aquaria were set up adjacent to the pot study with identical plant material and treatments. The aquaria were partitioned into eight cells with a volume equal to that of the pots. Soil temperature, $\mathrm{N}$-availability and clone were randomized within the aquaria, and all treatment combinations were replicated three times. As the aquaria did not drain freely, a clear polyvinyl chloride plastic rain-out shelter was installed to control water inputs and volumetric soil moisture was monitored using the TDR system. If soil moisture greatly exceeded that of the pots, water was withheld until evapotranspiration reduced it to the level of the pots. Similarly, water was added during extended dry periods. Roots growing within a predetermined area against one glass wall of each cell were traced onto acetate sheets approximately every
10 days, and cumulative root length production and mortality were determined over the course of the study following the method of Berntson and Bazzaz (1996). Between tracing dates the aquaria walls were covered with aluminum foil to shield the soil from light.

\section{Statistical analyses}

Because individual ramets varied in size at the beginning of the experiment, all statistical tests included an analysis of covariance (ANCOVA) to adjust for initial plant size. Data were log-transformed to normalize variances across treatments, meeting the assumptions of analysis of variance (ANOVA). This was confirmed by inspection of residuals and normal probability plots. Treatment main effects and interactions were analyzed as a completely random design (CRD) with three replications (Sokal and Rholf, 1995); the experiment was not blocked since there was no indication of environmental gradients within the experimental area. Shifts in biomass allocation were evaluated using allometric analysis (Troughton, 1955; Ledig et al., 1970), a statistically robust method of separating treatment effects from ontogenetic effects on growth. Allometric analysis consists of comparing the slopes of the log-log relationship between plant parts over time as affected by the experimental treatments. Statistically significant treatment effects are indicated by non-parallel slopes and tested using an ANCOVA between the respective plant parts (Niklas, 1994). We performed allometric analyses on the distribution of biomass between roots and shoots, and root and stems to remove possible effects of varying leaf phenology. Root production and mortality data were analyzed using repeated measures analysis following Pregitzer et al. (1995). To account for serial correlation of the root tracings, orthogonal quadratic polynomials were fitted to the data as calculated for unequally spaced sample dates (Robson, 1959; Meredith and Stehman, 1991). Coefficients from the polynomials were then used as primary data to test for significant treatment effects using standard ANOVA (Steel and Torrie, 1980).

\section{Results}

\section{Temperature control}

Over the course of the experiment, the groundwater cooling system effectively maintained temperature separation between soils in the low and high temperature treatments, although the separation was highly 
Table 1. Monthly mean soil temperature (standard deviation) of four different clones of aspen ramets grown at two levels of soil $\mathrm{N}$-availability and temperature for 98 days at the University of Michigan Biological Station, Pellston, Michigan. Pot codes are defined as: $\mathrm{H}-\mathrm{Ctr}$ - high temperature, center pot; L-Ctr - low temperature, center pot; H-Edge - high temperature, edge pot; L-Edge - low temperature, edge pot

\begin{tabular}{lllll}
\hline Month & H-Ctr & L-Ctr & H-Edge & L-Edge \\
\hline June (N=1431) & $19.83(5.10)$ & $13.14(2.37)$ & $21.61(5.67)$ & $14.55(1.78)$ \\
July (N=3516) & $19.27(4.21)$ & $12.24(0.69)$ & $19.41(4.64)$ & $12.42(0.86)$ \\
August $(\mathrm{N}=5226)$ & $17.15(3.90)$ & $13.20(0.87)$ & $17.25(3.86)$ & $13.68(1.40)$ \\
September (N=2640) & $15.60(3.41)$ & $13.22(0.74)$ & $15.81(3.17)$ & $13.59(1.22)$ \\
\hline
\end{tabular}

variable (Figure 1A). Low temperature pots averaged $13{ }^{\circ} \mathrm{C}$ over the course of the experiment, while the high temperature pots varied between 10 and $29^{\circ} \mathrm{C}$. Comparison of thermocouples at the center of the boxes and at the edge for both temperature treatments indicated that there was not much of a gradient within the boxes (Table 1; Figure 1B, C). Mean soil temperature differences between the low and high treatments (24 $\mathrm{h}$ averages) for June, July, August and September were $6.88{ }^{\circ} \mathrm{C}, 7.01{ }^{\circ} \mathrm{C}, 3.76{ }^{\circ} \mathrm{C}$, and $2.30{ }^{\circ} \mathrm{C}$, respectively. Although our control over temperature differences was limited, the water-cooled system accurately tracked the daily and seasonal fluctuations in temperature, which we feel is more realistic than a square-wave treatment (Figure 1). The spike in the low temperature treatment in early July (Figure 1B) was due to a 4-hour electrical failure, giving an indication of the ambient heat load on the pots.

\section{Photosynthesis}

Clear treatment effects were apparent on photosynthetic rates that persisted for the duration of the experiment (Figure 2). Clone was not a significant factor at any time, but high soil $\mathrm{N}$-availability resulted in $65 \%$ greater photosynthetic rates, averaged over all three harvests. This stimulation of photosynthesis was augmented by high soil temperature at the first and last harvests (53\% and 26\%, respectively), although the statistical significance of soil temperature was only marginal at the last harvest (Figure 2). Rates of photosynthesis increased throughout the experiment, even though leaves had begun to change color and senesce by the last harvest.

\section{Biomass accumulation}

By the end of the experiment, total plant dry mass ranged from approximately $2 \mathrm{~g}$ to over $9 \mathrm{~g}$ (Fig- ure $3 \mathrm{~A}$ ) and soil temperature and soil $\mathrm{N}$ availability were significant as main effects (Table 2). High soil temperature resulted in larger plants (37\%), but this generally occurred only under high $\mathrm{N}$ availability, although the temperature by $\mathrm{N}$-availability interaction was marginally significant $(P=0.08)$. High soil $\mathrm{N}$ availability usually resulted in larger plants $(62 \%)$ regardless of soil temperature. Root systems comprised the largest fraction of total plant mass, 63\% on average (Figure 3B), and therefore strongly influenced the whole-plant response to the treatments. Soil temperature, however, was only marginally significant for root biomass (Table 2). Averaged over other factors, the increase in root mass due to high soil $\mathrm{N}$-availability was $48 \%$. Stems were the next largest fraction, comprising $20 \%$ of total mass on average, and were significantly affected by a temperature by soil $\mathrm{N}$-availability interaction (Table 2). Stem mass increased significantly under high soil $\mathrm{N}$ at high temperature (135\%), but there was little or no response at low temperature (Figure 3C). Finally, leaf mass was significantly affected by clone and a temperature $\times$ soil $\mathrm{N}$-availability interaction (Table 2). Averaged over other factors, clone 42 had the smallest leaf mass $(0.55 \mathrm{~g})$, followed by clone $1(0.64 \mathrm{~g})$, clone $8(0.74 \mathrm{~g})$, and then clone $51(0.81 \mathrm{~g})$. The leaf response to the temperature $\times$ soil $\mathrm{N}$ interaction was similar to that for stem mass (Figure 3D); leaf mass increased under high $\mathrm{N}$-availability at high temperature (222\%), but at low temperature there was little or no response to soil $\mathrm{N}$-availability.

\section{Root length production and turnover}

Net root length production (production minus mortality) increased at a rapid rate early in the experiment, leveled off and finally declined by the end of the experiment (Figure 4A). It increased at high temper- 

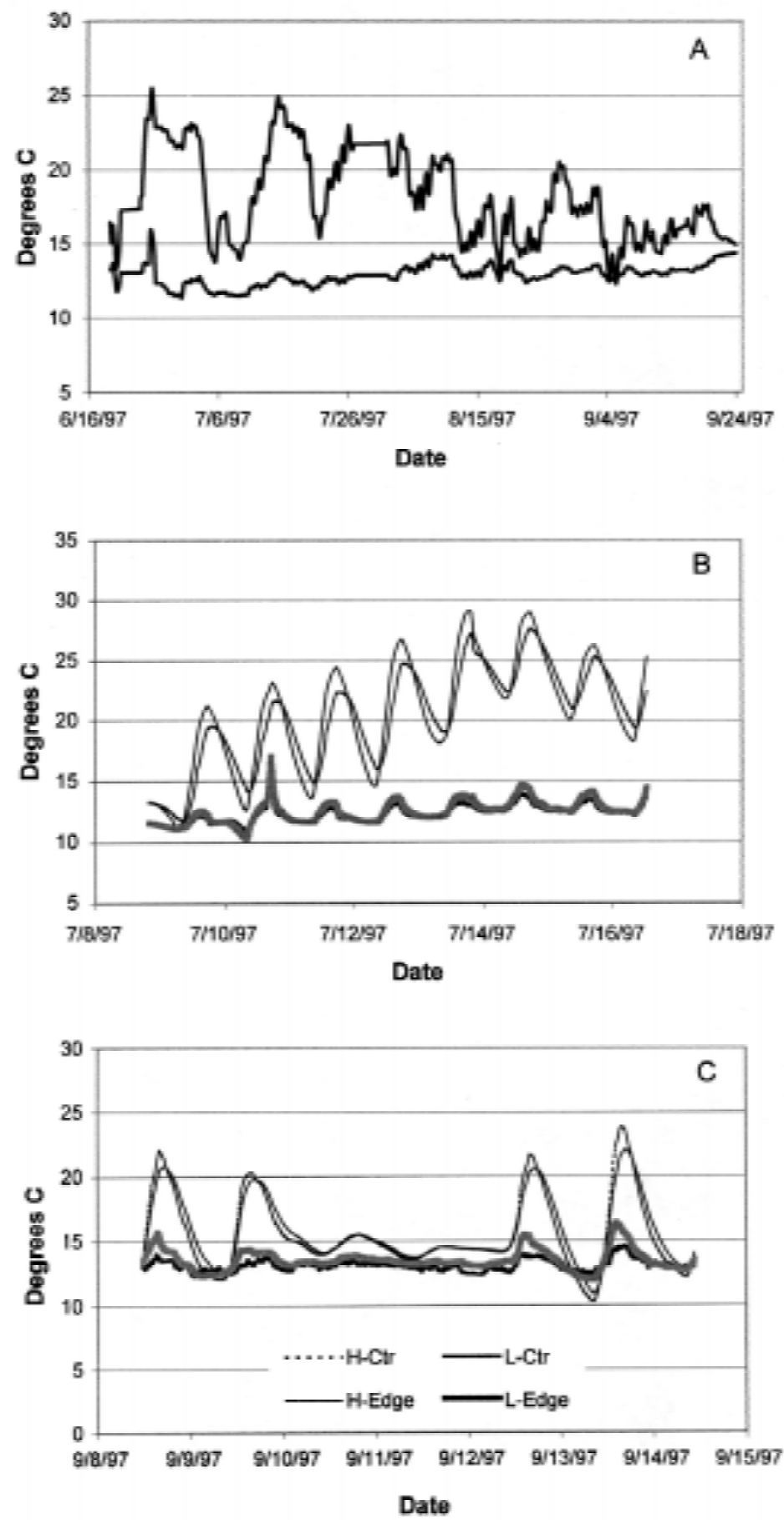

Figure 1. Pot temperature measured at mid-pot depth over the course of the growing season of four clones of aspen grown at two levels of soil $\mathrm{N}$-availability and temperature for 98 days at the University of Michigan Biological Station, Pellston, Michigan. Panel A - moving average (3.5 days) soil temperature in the high and low temperature treatments for the entire experiment; Panel B - soil temperature for a week early in the experiment; Panel $\mathrm{C}$ - soil temperature for a week late in the experiment. The legend for panels $\mathrm{B}$ and $\mathrm{C}$ is as defined in Table 1 .

ature, but the rate of increase was modified by soil $\mathrm{N}$-availability. This was indicated by a significant tem- perature effect in the mean and quadratric terms of the orthogonal polynomials used to analyze root produc- 


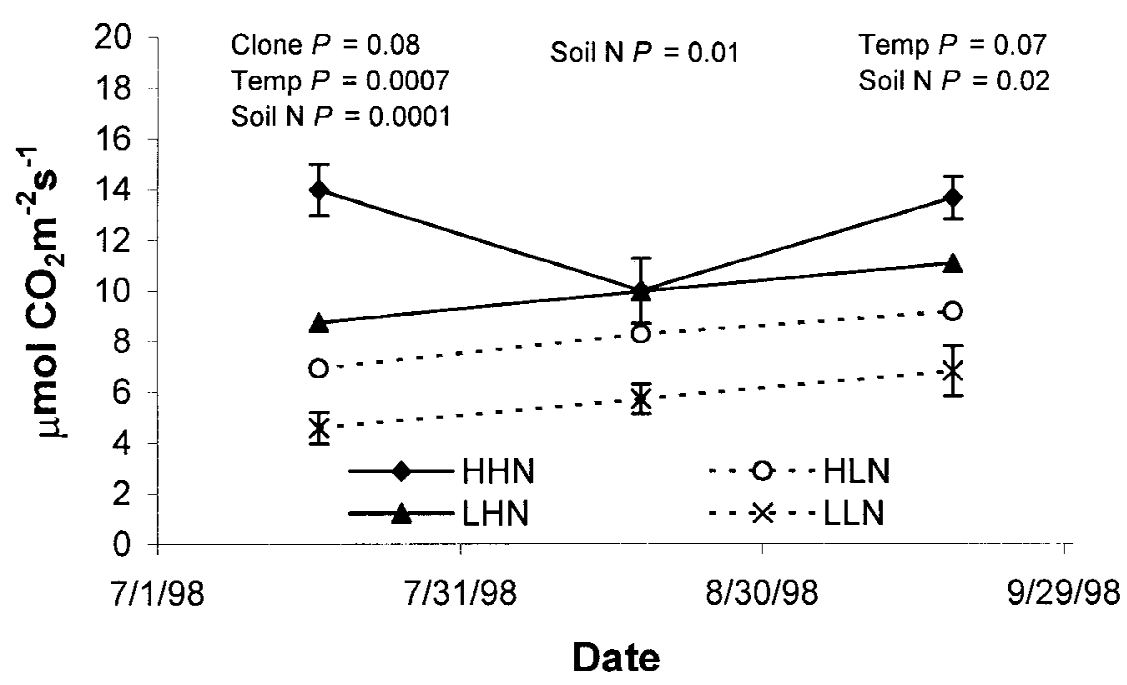

Figure 2. Mean photosynthetic rates of four aspen clones grown at two levels of soil N-availability and temperature for 98 days at the University of Michigan Biological Station, Pellston, Michigan. Bars are one standard error of the mean. Treatment codes are: HHN = high temperature, high $\mathrm{N}$-availability; HLN = high temperature, low $\mathrm{N}$-availability; LHN = low temperature, high $\mathrm{N}$-availability; LLN = low temperature, low N-availability.

tion responses $(P=0.0009$ and $P=0.0008$, respectively). It was also affected by soil $\mathrm{N}$-availability in the linear term $(P=0.04)$ and marginally by a temperature $\times$ soil $\mathrm{N}$-availability interaction in the quadratic term $(P=0.06)$. High soil $\mathrm{N}$-availability resulted in greater rates of net root production, but this only occurred at low temperature. Total root production (cumulative production plus cumulative mortality) responded similarly (Figure 4B). Temperature was significant for the mean $(P=0.0004)$ and quadratric $(P=0.01)$ terms, while soil $\mathrm{N}$-availability was significant in the linear term $(P=0.004)$. Finally, the rate of root mortality (both mean and linear terms) was significantly increased at high temperature $(P=0.0005)$, and the rate of increase (quadratic term) was influenced by soil $\mathrm{N}$-availability $(P=0.0032)$ (Figure $4 \mathrm{C})$.

\section{Root:shoot biomass partitioning}

The pattern of response of all biomass fractions to the treatments was unique and consistent for each clone; that is, roots responded similarly to the stems, which responded similarly to the leaves (Figure 3, panels B through D). This suggests there was no change in biomass allocation among plant parts induced by the treatments, which was tested with the allometric analyses (Table 3; Figure 5). Of the experimental treatments, only clone had a significant effect on the partitioning of biomass between the covariate (root mass) and response variables (shoot mass and stem mass) (Table 3). The clones exhibited a range of biomass allocation to shoots relative to roots, with Clone 8 having the highest and Clone 1 the lowest; the other two clones being intermediate (Figure 5A). This pattern persisted for the partitioning of biomass between roots and stems (Figure 5B). The R-square values for the ANCOVA models used in this analysis were 0.57 for roots:shoots and 0.77 for roots:stems, indicating a reasonable degree of confidence in fitting linear models.

\section{Discussion}

\section{The importance of soil temperature}

The quantity of $\mathrm{C}$ contained in terrestrial soils is a balance between rates of production and decomposition of organic litter (Olson, 1963). Modern society is altering environmental factors that directly affect forest physiology, growth and foodweb interactions. Therefore, it is likely that the accumulation of carbon in biomass and soils of future forests will differ from that of the past. Temperature exerts major control over global primary production (Lieth, 1975) and decomposition (Waring and Schlesinger, 1985), and therefore should be foremost in our investigations of forest responses to global change. An unanswered yet critical question is 
Table 2. $P$-values of ANOVA on biomass accumulation in four clones of aspen grown at two levels of soil $\mathrm{N}$-availability and temperature for 98 days at the University of Michigan Biological Station, Pellston, Michigan

\begin{tabular}{lllll}
\hline Source & Total $^{1}$ & Root & Stem & Leaf \\
\hline Initial Mass & $n s$ & $n s$ & $n s$ & $n s$ \\
Clone & $n s$ & $n s$ & $n s$ & 0.0089 \\
Temperature & 0.0471 & 0.0783 & $n s$ & 0.0004 \\
Temp*Clone & $n s$ & $n s$ & $n s$ & $n s$ \\
Soil N & 0.0009 & 0.0059 & 0.0015 & 0.0001 \\
Soil N*Clone & $n s$ & $n s$ & $n s$ & 0.0279 \\
Temp*Soil N & 0.0846 & $n s$ & 0.0308 & 0.0289 \\
Temp*Soil N*Clone & $n s$ & $n s$ & $n s$ & $n s$ \\
\hline
\end{tabular}

${ }^{1} n s$ indicates non-significant values.

Table 3. $P$-values of ANCOVA on biomass allocation in four clones of aspen grown at two levels of soil N-availability and temperature for 98 days at the University of Michigan Biological Station, Pellston, Michigan

\begin{tabular}{lll}
\hline Source $^{1}$ & Shoot $^{2}$ & Stem \\
\hline Root*Temp & $n s$ & $n s$ \\
Root*Soil N & $n s$ & $n s$ \\
Root*Temp*Soil N & $n s$ & $n s$ \\
Root*Clone & 0.0330 & 0.0043 \\
Root*Temp*Clone & $n s$ & $n s$ \\
Root*Soil N*Clone & $n s$ & $n s$ \\
Root*Temp*Soil N*Clone & $n s$ & $n s$ \\
\hline
\end{tabular}

${ }^{1}$ Denotes interaction term in the model between the covariate (root mass) and other experimental factors. Significant values indicate non-parallel slopes in the response between different levels of a factor.

${ }^{2} n s$ indicates non-significant values.

how warmer soils of the future will affect the production and turnover of fine roots, a major pathway for delivery of energy to carbon-limited soil microorganisms (Zak et al., 1993). Furthermore, soil warming has been shown to increase $\mathrm{N}$-mineralization in forest soils (Peterjohn et al., 1994), making it necessary to assess the effects of higher temperatures in soils of varying $\mathrm{N}$-availability.

We have attempted to address these questions using a simple, inexpensive technology that can be applied almost anywhere. The continuous flow of groundwater around the sealed pots maintained the low temperature pots at approximately $13{ }^{\circ} \mathrm{C}$, which is the average growing season soil temperature for forests of northern Lower Michigan (Hendrick and Pregitzer, 1997). We achieved good separation between the high and low soil temperature treatments, and pot temperatures precisely tracked daily and seasonal fluctuations in ambient conditions (Figure 1). The system provided minimal control over the magnitude of separation between high and low temperature pots, however we feel that the precise tracking of ambient temperature fluctuations more than compensated for this by exposing the plants to realistic temperature profiles as opposed to a square-wave treatment. One shortcoming of the technique, however, is that the difference in amplitude of daily temperature fluctuations between the high and low temperature pots (Figure 1B and C) may have unrecognized affects on physiology. 

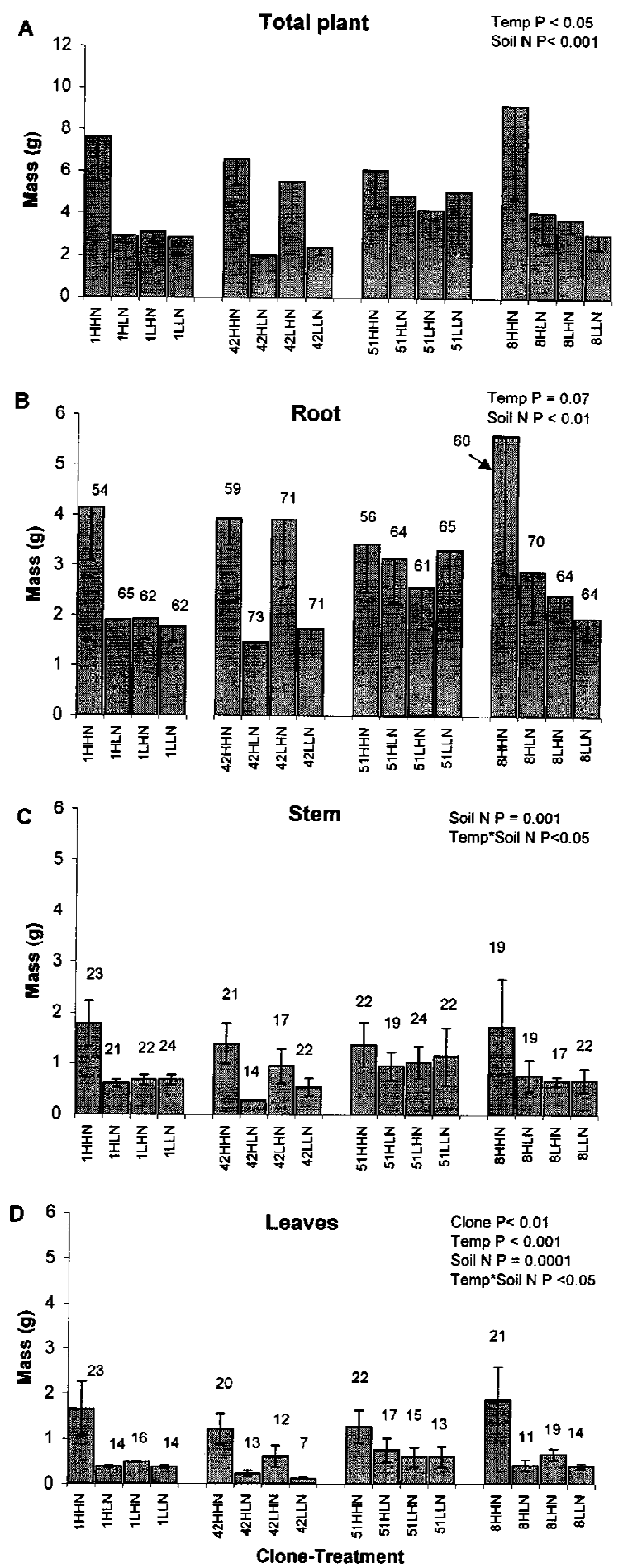

Figure 3. Mean mass of plant parts of four aspen clones grown at two levels of soil $\mathrm{N}$-availability and temperature for 98 days at the University of Michigan Biological Station, Pellston, Michigan. Bars are one standard error of the mean. Treatment codes are: clone number; $\mathrm{H}, \mathrm{L}=$ high and low temperature, respectively; $\mathrm{HN}, \mathrm{LN}=$ high and low nitrogen availability, respectively. Numbers above bars are percentage total plant biomass comprised by respective plant parts. Note change of scale for Total plant.
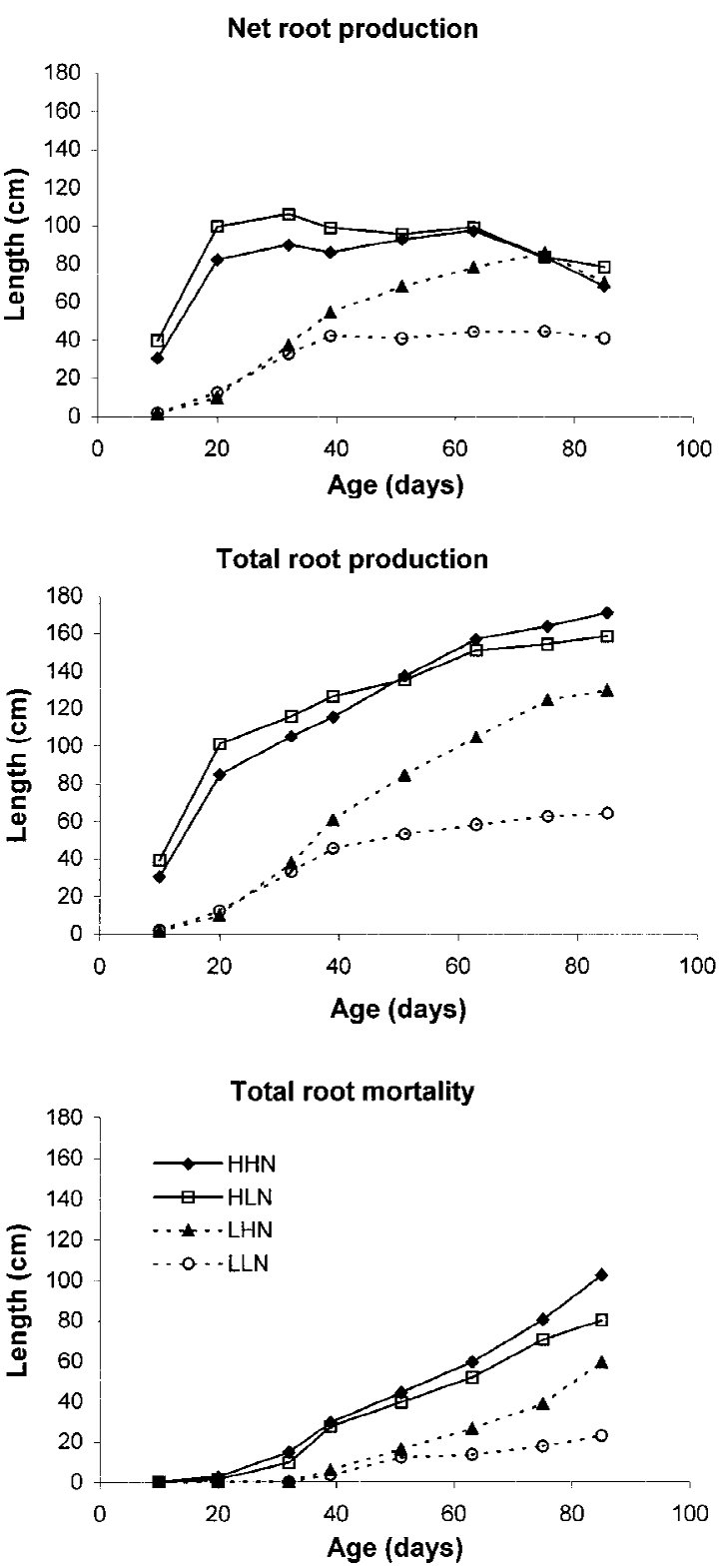

Figure 4. Cumulative root length production and mortality of four clones of aspen grown at two levels of soil $\mathrm{N}$-availability and temperature for 98 days at the University of Michigan Biological Station, Pellston, Michigan.

\section{Photosynthesis and growth}

Our first hypothesis was that trembling aspen would exhibit increased rates of photosynthesis and growth at elevated soil temperatures. Numerous investigators have demonstrated a strong, positive relationship between photosynthesis in forest tree species and soil temperature (Day et al., 1991; Lippu and Puttonen, 

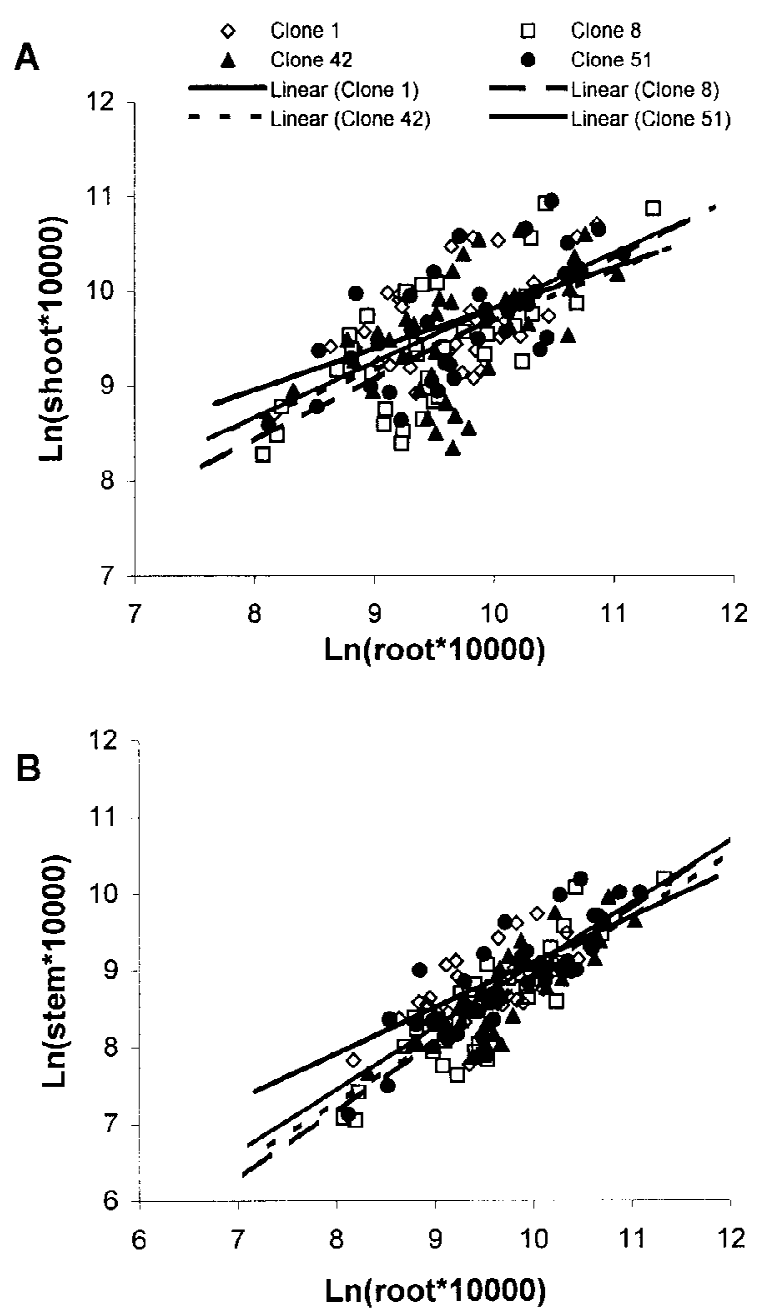

Figure 5. Allometric relationships between plant parts of four clones of aspen grown at two levels of soil $\mathrm{N}$-availability and temperature for 98 days at the University of Michigan Biological Station, Pellston, Michigan. Panel A - ln shoot vs. ln root; Panel B $-\ln$ stem vs. $\ln$ root.

1991; Landhäusser et al., 1996); moreover, soil temperature may be a better predictor of carbon assimilation than air temperature (Delucia, 1986; Delucia and Smith, 1987; Jurik et al., 1988; Schwarz et al., 1997). Our results with trembling aspen are in agreement with these findings and support our first hypothesis. Photosynthesis increased $65 \%$ in response to higher soil $\mathrm{N}$-availability and this response was augmented by the additive effect of elevated soil temperature for the duration of the experiment (Figure 2). The enhanced carbon assimilation translated into greater total plant biomass (Figure 3) due to increases in all organ systems (roots, leaves, stems), again primarily driven by high soil $\mathrm{N}$-availability, but augmented by elevated soil temperature (Table 2). This synergistic effect of various soil properties on growth has been reported by others (Parsons et al., 1994) and will probably be an important controller of forest responses to changing environmental conditions. Increased biomass production at elevated soil temperature has also been reported by other investigators (Lawrence and Oechel, 1984; Kaspar and Bland, 1992; Landhäusser et al., 1996), and in conjunction with 'fertilization' from elevated atmospheric $\mathrm{CO}_{2}$ and nitrogen deposition, may contribute to enhanced carbon sequestration in future forest ecosystems.

Although clonal variation in trembling aspen can be important for leaf phenology and carbon gain (Barnes, 1959; Kubiske et al., 1998), it did not appear to greatly affect photosynthesis or growth in this study (Table 2; Figure 2). There was a marginally significant effect of clone on photosynthesis $(P=0.08)$ early in the experiment, but this did not persist over the course of the growing season. In addition, certain clones experienced earlier leaf senescence resulting in lower final leaf biomass (Figure 3D). These clonal responses were of insufficient magnitude to have a statistically significant effect on final biomass accumulation (Figure $3 \mathrm{~A}$ ), which was dominated by the response of roots and stems.

\section{Root length production and turnover}

Although root longevity in poplar has been shown to decline due to infection by arbuscular mycorrhizal fungi (Hooker et al., 1995), very little work has been done on the effects of soil warming on the production and turnover of roots in forest tree species (Kaspar and Bland, 1992). Redmond (1955) demonstrated that rootlet mortality in yellow birch (Betula alleghaniensis Britton) was correlated to soil temperature, and Tabbush (1986) reported higher numbers of new roots in Sitka spruce (Picea sitchensis (Bong.) Carr.) and Douglas-fir (Pseudotsuga menziesii (Mirbel) Franco) grown at higher soil temperatures. Tryon and Chapin (1983) found increased root elongation rates in a variety of taiga tree species as soils warmed over the course of the growing season. It is also known that soil temperature affects root growth, water relations and survival of out-planted seedlings (Lyr and Hoffman, 1967; Lopushinsky and Kaufman, 1984; Sands, 1984; Grossnickle and Blake, 1985).

We hypothesized that the rate of root production and mortality (turnover) would increase at elevated 
soil temperature, resulting in greater rates of carbon input to soils. Our study supports this hypothesis, showing that elevated soil temperature resulted in increased cumulative root production and mortality (Figure 4). In agreement with Pregitzer et al. (1995), we found soil $\mathrm{N}$-availability to exert strong control over root dynamics and it modified the temperature response. At low soil temperature, root production and mortality increased much more in high $\mathrm{N}$-availability soil compared to low $\mathrm{N}$-availability soil, resulting in greater net root production. In contrast, at high soil temperature, $\mathrm{N}$-availability had little effect on root dynamics. If similar responses to soil warming occur in aspen-dominated ecosystems, our data suggest that substantial increases in root turnover are possible at sites of both high and low soil $\mathrm{N}$-availability. A possible mechanism for this might be increased $\mathrm{N}$ mineralization in low $\mathrm{N}$-availability soils, resulting in greater root production and decreased root longevity.

Although elevated soil temperature may lead to greater litter inputs to forest soils through higher rates of root turnover (Figure 4C), it may also contribute to greater ecosystem losses of $\mathrm{C}$ through its effects on autotrophic respiration. It is well established that root respiration increases with temperature (Billings et al., 1977; Linder and Troeng, 1981; Lawrence and Oechel, 1983; Burton et al., 1996; Boone et al., 1998), with a $Q_{10} \geq 2$ (see Burton et al., 1996). Higher maintenance respiration rates may be associated with the shorter root life spans, as has been shown for leaves (Eissenstat, 1992). In addition, the higher production of roots at elevated soil temperature (Figure 4B) should increase root growth respiration (Waring and Schlesinger, 1985), and combined with greater maintenance respiration, could significantly increase fluxes of $\mathrm{C}$ from forest soils to the atmosphere. It should be noted, however, that not all investigators have found simple, direct relationships between root respiration and soil temperature (Fitter et al., 1997, 1998).

Midway through the study, the rate of increase in cumulative root production declined while cumulative mortality continued to increase at an increasing rate (Figure 4B, C). This response was especially pronounced at high soil temperature and resulted in a declining rate of net root production (Figure 4A). Greater root mortality relative to production, combined with the generally greater root biomass at high temperature, would indicate substantially greater inputs of carbon to warmer soils late in the growing season. A key uncertainty regarding $\mathrm{C}$ storage in soils is the degree to which increasing rates of decomposition will consume the additional root carbon.

\section{Biomass allocation}

As mentioned, experimental warming of forest soil has been shown to increase N-mineralization (Peterjohn et al., 1994) and increased $\mathrm{N}$-availability has been shown to reduce biomass allocation to roots in tree seedlings (Griffin et al., 1995; Gebauer et al., 1996). Therefore, if soils warm appreciably in response to global change it is possible this will be accompanied by reduced allocation of biomass to roots, representing reduced carbon inputs belowground. We hypothesized that high soil $\mathrm{N}$-availability would reduce biomass allocation to roots irrespective of soil temperature. Contrary to our hypothesis, we found that the only factor controlling biomass allocation in this study was clone (Table 3). The allometric analysis indicated that Clone 1 had the greatest relative allocation of biomass to roots and Clone 8 the least (Figure 5). As both of these clones are of the late leaf-fall phenology type, it is clear that biomass allocation patterns may vary independent of leaf phenology. In addition, these results suggest there is probably a range of biomass allocation patterns in the field, depending on the clonal composition of the populations, and that biomass allocation is under strong genetic rather than environmental control (Gedroc et al., 1996; King et al., 1999). From a global change perspective, the relevant finding is that trembling aspen will not alter biomass allocation and therefore proportional $\mathrm{C}$ inputs to soils in response to soil warming. As this experiment was done with very small plants grown in pots, however, further studies using field-grown trees are necessary to determine the generality of these findings.

\section{Soil temperature, northern forests and global change}

If results from this study of small plants grown in pots extends to more natural ecosystems, trembling aspen may have the potential for enhanced photosynthesis and growth in response to soil warming at sites of both high and low $\mathrm{N}$-availability. An immediate consequence of this will be greater inputs of $\mathrm{C}$ and nutrients to forest soils due to greater rates of biomass production above- and belowground. In addition, higher rates of root production and mortality should substantially augment $\mathrm{C}$ delivery to forest soils and possibly result in greater nutrient availability in the 
future. The net effect of these responses on $\mathrm{C}$ storage in forest ecosystems will hinge on the degree to which decomposition and $\mathrm{C}$ transformations in the soil are stimulated by a warmer environment.

\section{Acknowledgements}

We would like to acknowledge the continued support of our global change research by the University of Michigan Biological Station. Special thanks go to Bob Van de Kopple and Chris Vogel for technical advice and helpful discussions. Mark Kubiske provided invaluable assistance with some of the statistical analyses. Jared DeForest helped with the harvests, and Mike Hyslop and Dave Karnosky provided computer equipment for the root turnover analysis. This research was supported by the U.S. Department of Energy PER and U.S. Forest Service Global Change Research programs.

\section{References}

Alban D H and Perala D A 1992 Carbon storage in Lake States aspen ecosystems. Can. J. For. Res. 22, 1107-1110.

Amthor J S 1995 Terrestrial higher-plant response to increasing atmospheric $\left[\mathrm{CO}_{2}\right]$ in relation to the global carbon cycle. Global Change Biol. 1, 254-274.

Barnes B V 1959 Natural variation and clonal development of Populus tremuloides and P. grandidentata in Northern Lower Michigan. Ph.D. Thesis, The University of Michigan, Ann Arbor. 344 p.

Barnes B V and Wagner Jr W H 1981 Michigan trees. The University of Michigan Press, Ann Arbor. 383 p.

Berntson G M and Bazzaz F A 1996 The allometry of root production and loss inseedlings of Acer rubrum (Aceraceae) and Betula papyrifera (Betulaceae): Implications for root dynamics in elevated $\mathrm{CO}_{2}$. Am. J. Bot. 83, 608-616.

Billings W D, Peterson K M, Shaver G R and Trent A W 1977 Root growth, respiration, and carbon dioxide evolution in an arctic tundra soil. Art. Alp. Res. 9, 129-137.

Billings W D, Luken J O, Mortensen D A and Peterson K M 1982 Arctic tundra: a source or sink for atmospheric carbon dioxide in a changing environment? Oecologia 53, 7-11.

Boone, R D, Nadelhoffer K J, Canary J D and Kaye J P 1998. Roots exert a strong influence on the temperature sensitivity of soil respiration. Nature 396: 570-572.

Burton A J, Pregitzer K S, Zogg G P and Zak D R 1996 Latitudinal variation in sugar maple fine root respiration. Can. J. For. Res. 26, 1761-1768.

Day T A, Heckathorn S A and Delucia E H 1991 Limitations of photosynthesis in Pinus taeda L. (loblolly pine) at low soil temperatures. Plant Physiol. 96, 1246-1254.

Delucia E H 1986 Effect of low root temperature on net photosynthesis, stomatal conductance and carbohydrate concentration in Engelman spruce (Picea engelmannii Parry ex Engelm.) seedlings. Tree Physiol. 2, 143-154.
Delucia E H and Smith W K 1987 Air and soil temperature limitation on photosynthesis in Engelman spruce during summer. Can. J. For. Res. 17, 527-533.

Eissenstat D M 1992 Costs and benefits of constructing roots of small diameter. J. Plant Nutr. 15, 763-782.

Fitter A H, Graves J D, Wolfenden J, Self G K, Brown T K, Bogie D and Mansfield T A 1997 Root production and turnover and carbon budgets of two contrasting grasslands under ambient and elevated atmospheric carbon dioxide concentrations. New Phytol. 137, 247-255.

Fitter A H, Graves J D, Self G K, Brown T K, Bogie D S and Taylor K 1998 Root production, turnover and respiration under two grassland types along an altitudinal gradient: influence of temperature and solar radiation. Oecologia 114, 20-30.

Fogel R 1983 Root turnover and productivity of coniferous forests. Plant Soil 71, 75-85.

Galloway J N, Schlesinger W H, Levy II H, Michaels A and Schnoor J L 1995 Nitrogen fixation: Anthropogenic enhancementenvironmental response. Global Biogeochem. Cycles 9, 235252.

Ganopolski A, Kubatzki C, Claussen M, Brovkin V and Petoukhov V 1998 The influence of vegetation-atmosphere-ocean interaction on climate during the Mid-Holocene. Science 280, 1916-1919.

Gebauer R L E, Reynolds J F and Strain B R 1996 Allometric relations and growth in Pinus taeda: the effect of elevated $\mathrm{CO}_{2}$ and changing N availability. New Phytol. 134, 85-93.

Gedroc J J, McConnaghay K D M and Coleman J S 1996 Plasticity in root/shoot partitioning: optimal, ontogenetic, or both? Func. Ecol. 10, 44-50.

Griffin K L, Winner W E and Strain B R 1995 Growth and dry matter partitioning in loblolly and ponderosa pine seedlings in response to carbon and nitrogen availability. New Phytol. 129, 547-556.

Grossnickle S C and Blake T J 1985 Acclimation of cold-stored jack pine and white spruce seedlings: effect of soil temperature on water relation patterns. Can. J. For. Res. 15, 544-550.

Hendrick R L and Pregitzer K S 1993 Patterns of fine root mortality in two sugar maple forests. Nature 361, 59-61.

Hendrick R L and Pregitzer K S 1997 The relationship between fine root demography and the soil environment in northern hardwood forests. Ecoscience 4, 99-105.

Hobbie S A 1996 Temperature and plant species control over litter decomposition in Alaskan tundra. Ecol. Mono. 66, 503-522.

Hooker, J E, Black K E, Perry R L and Atkinson D 1995 Arbuscular mycorrhizal fungi induced alteration to root longevity in poplar. Plant Soil 172, 327-329.

Houghton J T, Meira Filho L G, Callander B A, Harris N, Kattenberg A and Maskell K 1996 Technical summary. In Climate change 1995: The science of climate change. Contribution of Working Group 1 to the Second Assessment Report of the Intergovernmental Panel on Climate Change. Eds J T Houghton, L G Meira Filho, B A Callander, N Harris, A Kattenberg and K Maskell. pp 13-49. Cambridge University Press, Cambridge.

Jurik T W, Briggs G M and Gates D M 1988 Springtime recovery of photosynthetic activity of white pine in Michigan. Can. J. Bot. $66,138-141$.

Kaspar T C and Bland W L 1992 Soil temperature and root growth. Soil Sci. 154, 290-299.

King J S, Albaugh T J, Allen H L and Kress L W 1999 Standlevel allometry in Pinus taeda as affected by irrigation and fertilization. Tree Physiol. (In review).

Kubiske M, Pregitzer K S, Zak D R and Mikan C J 1998 Growth and carbon allocation of Populus tremuloides clones in response 
to atmospheric $\mathrm{CO}_{2}$ and soil nitrogen availability. New Phytol. 140, 251-260.

Landhäusser S M, Wein R W and Lange P 1996 Gas exchange and growth of three arctic tree-line tree species under different soil temperature and drought preconditioning regimes. Can. J. Bot. 74, 686-693.

Lawrence W T and Oechel W C 1983 Effect of soil temperature on the carbon exchange of seedlings. I. Root respiration. Can. J. For. Res. 3, 840-849.

Lawrence W T and Oechel W C 1984 Soil temperature effects on carbon exchange in taiga trees. Tasks Veg. Sci. 13, 127-136.

Ledig F T, Bormann F H and Wenger K F 1970 The distribution of dry matter growth between shoot and roots in loblolly pine. Bot. Gaz. 131, 349-359.

Lieth H 1975 Modeling the primary productivity of the world. In Primary Productivity of the Biosphere. Eds H Lieth and R H Whittaker. pp 237-263. Springer-Verlag, New York.

Linder S and Troeng E 1981 The seasonal variation in stem and coarse root respiration of a 20 -year old Scots pine (Pinus sylvestris L.). Mitt. Fors. Bund. Wien 142, 125-139.

Lippu J and Puttonen P 1991 Soil temperature limitations on gas exchange in 1-year-old Pinus sylvestris (L.) seedlings. Scand. J. For. Res. 6, 73-78.

Lopushinsky W and Kaufman M R 1984 Effects of cold soil on water relations and spring growth of Douglas-fir seedlings. For. Sci. 30, 628-634.

Lyr H and Hoffman G 1967 Growth rates and growth periodicity of tree roots. Int. Rev. For. Res. 2, 181-236.

Marshall J D and Waring R H 1985 Predicting fine root production and turnover by monitoring root starch and soil temperature. Can. J. For. Res. 15, 791-800.

Melillo J M, Prentice I C, Farquhar G D, Schulze E.-D and Sala O E 1996 Terrestrial biotic responses to environmental change and feedbacks to climate. In Climate change 1995: The science of climate change. Contribution of Working Group 1 to the Second Assessment Report of the Intergovernmental Panel on ClimateChange. Eds J T Houghton, L G Meira Filho, B A Callander, N Harris, AKattenberg and K Maskell. pp 449-481. Cambridge University Press, Cambridge.

Meredith M P and Stehman, S V 1991 Repeated measures experiments in forestry: focus on analysis of response curves. Can. J. For. Res. 21, 957-965.

Niklas K J 1994 Plant allometry: The scaling of forms and process. University of Chicago Press, Chicago, IL. 395 p.

Norby R J, Wullschleger S D and Gunderson C A 1996 Tree responses to elevated $\mathrm{CO}_{2}$ and implications for forests. In Carbon dioxide and terrestrial ecosystems. Eds G W Koch and H A Mooney. pp 1-21. Academic Press, Inc., San Diego.

Oechel W C and Vourlitis G L 1996 Direct effects of elevated $\mathrm{CO}_{2}$ on arctic plant and ecosystem function. In Carbon dioxide and terrestrial ecosystems. Eds G W Koch and H A Mooney. pp 163176. Academic Press, Inc., San Diego.

Olson J S 1963 Energy storage and the balance of producers and decomposers in ecological systems. Ecology 44, 322-331.

Parsons A N, Welker J M, Wookey P A, Press M C, Callaghan T V and Lee J A 1994 Growth responses of four sub-Arctic dwarf shrubs to simulated environmental change. J. Ecol. 82, 307-318.
Perala D A 1990 Populus tremuloides Michx., trembling aspen. In Silvics of North America, Volume 2, Hardwoods. Eds R M B Burns and B H Honkala. pp 555-569. USDA Forest Service Handbook Number 654, Washington DC.

Peterjohn W T, Mellilo J M, Steudler P A, Newkirk K M, Bowles F $\mathrm{P}$ and Aber J D 1994 Responses of trace gas fluxes and N availability to experimentally elevated soil temperature. Ecol. App. 4, 617-625.

Pregitzer K S, Hendrick R L and Fogel 1993 The demography of fine roots in response to patches of water and nitrogen. New Phytol. $125,575-580$.

Pregitzer K S, Zak D R, Curtis P S, Kubiske M E, Teeri J A and Vogel C S 1995 Atmospheric $\mathrm{CO}_{2}$, soil nitrogen and turnover of fine roots. New Phytol. 129, 579-585.

Randlett D L, Zak D R, Pregitzer K S and Curtis P S 1996 Elevated atmospheric carbon dioxide and leaf litter chemistry: Influences on microbial respiration and net nitrogen mineralization. Soil Sci. Soc. Am. J. 60, 1571-1577.

Redmond D R 1955 Studies in forest pathology. XV. Rootlets, mycorrhiza, and soil temperatures in relation to birch dieback. Can. J. Bot. 33, 595-627.

Robson D S 1959 A simple method for constructing orthogonal polynomials when the independent variable is unequally spaced. Biometrics 15, 187-191.

Sands R 1984 Transplanting stress in Radiata pine. Aust. For. Res. 14, 67-72.

Schwarz P A, Fahey T J and Dawson T E 1997 Seasonal air and soil temperature effects on photosynthesis in red spruce (Picea rubens) saplings. Tree Physiol. 17, 187-194.

Sokal R R and Rohlf F J 1995 Biometry. 3rd edition. W.H. Freeman and Company, NewYork. 887 p.

Steel R G D and Torrie J H 1980 Principles and procedures of statistics. 2nd edition. McGraw-Hill, New York. 633 p.

Tabbush P M 1986 Rough handling, soil temperature, and root development in outplanted Sitka spruce and Douglas fir. Can. J. For. Res. 16, 1385-1388.

Tissue D T, Thomas R B and Strain B R 1996 Growth and photosynthesis of loblolly pine (Pinus taeda) after exposure to elevated $\mathrm{CO}_{2}$ for 19 months in the field. Tree Physiol. 16, 49-59.

Troughton A 1955 The application of the allometric formula to the study of the relationship between roots and shoots of young grass plants. Ag. Prog. 30, 59-65.

Tryon P R and Chapin III F S 1983 Temperature control over root growth and root biomass in taiga forest trees. Can. J. For. Res. $13,827-833$.

Vitousek P M, Aber J D, Howarth R W, Likens G E, Matson P A, Schindler D W, Schlesinger W H and Tilman D G 1997 Human alterations of the global nitrogen cycle: sources and consequences. Ecol. Appl. 7, 737-750.

Waring R H and Schlesinger W H 1985 Forest ecosystems: Concepts and management. Academic Press, San Diego. 340 p.

Zak D R and Pregitzer K S 1990 Spatial and temporal variability of nitrogen cycling innorthern Lower Michigan. For. Sci. 36, $367-$ 380.

Zak D R, Pregitzer K S, Curtis P S, Teeri J A, Fogel R and Randlett D L 1993 Elevated atmospheric $\mathrm{CO}_{2}$ and feedback between carbon and nitrogen cycles. Plant Soil 151, 105-117. 